\title{
Umowa jako prawna forma działania administracji publicznej w polskiej i niemieckiej doktrynie prawa publicznego ${ }^{1}$
}

\section{Wprowadzenie}

Z przyjętej w doktrynie ogólnej klasyfikacji ${ }^{2}$ prawnych form działania administracji ${ }^{3}$ wynika, że umowa stanowi istotną prawną formę działania

${ }^{1}$ Niniejszy artykuł powstał w ramach stypendium przyznanego przez fundację Fritz Thysssen Stiftung w ramach postępowania o sygn. 40.18.0.011RE na pobyt badawczy w Kommunalwissenschaftliches Institut (KWI) der Universität Potsdam.

${ }^{2}$ Nie sposób w tym miejscu przytoczyć w całości obszernej literatury dotyczącej prawnych form działania administracji - zob. np.: K.W. Kumaniecki, Akt administracyjny: studya nad istota aktu administracyjnego z uwzględnieniem zasadniczego orzecznictwa austryackiego trybunału administracyjnego, Kraków 1913; M. Zimmermann, Formy działania administracji i administracyjne, w: Prawo administracyjne, cz. 2, pod red. M. Jaroszyńskiego, Warszawa 1952, s. 91 i n.; M. Jaroszyński, M. Zimmermann, W. Brzeziński, Rozdziat IX, Formy działania administracji państwowej. Akt administracyjny, w: Polskie prawo administracyjne. Część ogólna, pod red. M. Jaroszyńskiego, Warszawa 1956; J. Starościak, Prawne formy działania administracji, Warszawa 1957; idem, Prawne formy i metody działania administracji, w: System prawa administracyjnego, t. 3, pod red. T. Rabskiej, J. Łętowskiego, Warszawa 1978, s. 39-129; J. Łętowski, Prawo administracyjne. Zagadnienia podstawowe, Warszawa 1990, s. 128-209; A. Wiktorowska, Kierunki zmian w teorii prawnych form działania administracji, w: Koncepcja systemu prawa administracyjnego. Zjazd Katedr Prawa Administracyjnego i Postępowania Administracyjnego, Zakopane 24-27 września 2006 r., pod red. J. Zimmermanna, Warszawa 2007, s. 359-384. Ponadto wskazuje się na bardzo dużą rolę pojęcia prawnych form działania administracji w nauce prawa administracyjnego - zob. K.M. Ziemski, Określenie pojęcia formy prawnej działania administracji publicznej, w: Prawne formy działania administracji, seria System Prawa Administracyjnego, pod red. R. Hausera, Z. Niewiadomskiego, A. Wróbla, t. 5, Warszawa 2013, s. 4-5.

${ }^{3}$ Por. J. Starościak, Prawne formy działania administracji, s. 9-11. Według definicji sformułowanej przez autora prawna forma działania administracji to określony prawem 
administracji. Twierdzenie to, którego autorem, w zupełnie innej rzeczywistości społecznej i gospodarczej, był J. Starościak, jest aktualne także na gruncie obecnego systemu społeczno-gospodarczego.

Współcześnie, biorąc pod uwagę znaczącą obecność umowy w obowiązującym porządku prawnym ${ }^{4}$, doktryna prawa administracyjnego dokonała jej obszernej charakterystyki prawnej ${ }^{5}$. Należy przy tym pamiętać, że podstawową prawną formę działania administracji wciąż stanowi indywidualny akt administracyjny, który jest uregulowany przede wszystkim w Kodeksie postępowania administracyjnego ${ }^{6}$ pod postacią decyzji administracyjnej (art. 1, 104, 105 i 107 k.p.a.). Stosowanie zaś umów w administracji obarczone jest licznymi problemami natury prawnej, które wynikaja, w większości, choć nie wyłącznie, z braku odpowiedniej regulacji prawnej w tym obszarze. Dlatego tym ważniejsze są badania doktryny prawa administracyjnego zmierzające do uporządkowania tego zagadnienia, zwłaszcza że obecny stan stanowienia i stosowania prawa w tym zakresie nie jest zadowalający.

Podstawowym przedmiotem rozważań jest analiza umowy jako prawnej formy działania administracji. W tym kontekście nacisk położono na posługiwanie się przez administrację umowami w celu realizacji zadań publicznych.

W związku ze szczególnymi cechami umów wykorzystywanych w działalności administracji prowadzone są poszukiwania nowej klasyfikacji prawnej dla takich umów. W tym kontekście analizie zostanie

typ czynności podmiotu administracji publicznej (J. Starościak, Prawne formy działania administracji...; idem, Prawne formy i metody działania administracji, w: System prawa administracyjnego, t. 3, pod red. T. Rabskiej, J. Łętowskiego, Warszawa 1978, s. 40).

${ }^{4}$ B. Jaworska-Dębska, Umowy we współczesnej administracji, w: Umowy w administracji, pod red. J. Bocia, L. Dziewięckiej-Bokun, Wrocław 2008, s. 14.

${ }^{5}$ Zob. np. M. Kania, Umowa jako prawna forma działania administracji publicznej, w: Publiczne prawo gospodarcze, seria System Prawa Administracyjnego, pod red. R. Hausera, Z. Niewiadomskiego, A. Wróbla, t. 8B, Warszawa 2013, s. 510-543; A. Doliwa, S. Prutis, Wypieranie prawa administracyjnego przez prawo cywilne, seria Kryzys prawa administracyjnego, pod red. D. Kijowskiego, P.J. Suwaj, t. 3, Warszawa 2012, s. 300. Z drugiej strony nawet współcześnie zdarza się, że rola umowy w działalności administracji nie jest dostrzegana. Przykładowo, A. Adamczyk wśród prawnych form działania administracji wyróżnia akty generalne, indywidualne akty administracyjne oraz czynności faktyczne, w ogóle nie omawiając umów w działalności administracji - zob. A. Adamczyk, Publicznoprawne formy działania administracji. Teoria i praktyka, Warszawa 2013, s. 332.

${ }^{6}$ Ustawa z dnia 14 VI 1960 r. Kodeks postępowania administracyjnego (tekst jedn. Dz.U. 2016, poz. 23 ze zm.), dalej „k.p.a.”. 
poddana umowa administracyjna jako alternatywa dla tradycyjnych form prawnych działania administracji - zarówno w świetle polskiej, jak i niemieckiej doktryny prawa publicznego.

Należy ponadto zadać pytanie, czy umowa, a jeśli tak, to jaka (cywilnoprawna czy publicznoprawna), jest właściwą z punktu widzenia praw i wolności obywateli formą prawną działania administracji publicznej do realizacji jej zadań7.

\section{Umowa cywilnoprawna}

W doktrynie polskiego prawa publicznego ustalono, że umowa, obok porozumienia administracyjnego, ugody, a także według niektórych autorów (J. Zimmermann) przyrzeczenia administracyjnego, należy do zewnętrznych, wielostronnych, prawnych form działania administracji ${ }^{8}$. Taka umowa występuje zarówno w sferze prywatnoprawnej, jak i publicznoprawnej. Pogląd ten może wydawać się kontrowersyjny w świetle prawa cywilnego, dla którego, ze swej istoty, umowa ma tradycyjnie charakter prywatnoprawny, dotycząc relacji między podmiotami prywatnymi.

${ }^{7}$ Przez zwrot „właściwy” autor rozumie: umożliwiający optymalne realizowanie zadań publicznych podejmowanych przez administrację, a także zapewniający najlepszy poziom ochrony prawnej z punktu widzenia chronionych przez ustawodawcę wartości. Do uznania, że pewna prawna forma działania jest właściwa, nie jest wystarczające, by została zdeterminowana przepisami prawnymi.

Jak podkreśla, odnosząc się do pomocy publicznej udzielanej przedsiębiorcom, B. Popowska: „nie wszystkie rozwiązania dotyczące prawnych form działania pozwalają zrealizować cele związane z pomocą publiczną i nie wszystkie w jednakowym stopniu odpowiadają wymogom, jakie państwo stawia przed administracją w kontaktach z obywatelem (podmiotem usytuowanym na zewnątrz administracji). Nadto, wybór prawnej formy działania czy występowanie obu form w określonej sekwencji w różny sposób zapewnia realizację konstytucyjnych praw i wolności obywatelskich, takich jak na przykład prawo do udziału w postępowaniu, w którym rozstrzyga się o interesie prawnym strony czy prawo do sądu" (B. Popowska, Decyzja i umowa jako formy działania podmiotów administracji gospodarczej; konkurencja, wspótwystępowanie czy alternatywa?, w: Instrumenty i formy prawne działania administracji gospodarczej, pod red. B. Popowskiej, K. Kokocińskiej, Poznań 2009, s. 79.

${ }^{8}$ W. Chróścielewski, Imperium a gestia $w$ działaniach administracji publicznej ( $w$ świetle doktryny i zmian ustawodawczych lat 90.), „Państwo i Prawo” 1995, z. 6, s. 49-59; J. Zimmermann, Prawo administracyjne, Warszawa 2006, s. 285, 288-289 i n.; por. też M. Kotulska, M. Książek, M. Podleśny, Ugoda w prawie niemieckim a instytucja ugody w kodeksie postępowania administracyjnego (studium prawno-porównawcze), w: Umowy w administracji, s. 481. 
W stanowionym prawie wskazuje się na zróżnicowane formy prawa cywilnego, w których administracja ma realizować zadania publiczne ${ }^{9}$. W efekcie administracja, oprócz posługiwania się władczymi formami prawnymi ${ }^{10}$, posługuje się także konsensualnymi formami prawnymi działania ${ }^{11}$, w szczególności uregulowanymi w Kodeksie cywilnym ${ }^{12}$.

Niektórzy autorzy idą dalej, stwierdzając, że administracja władcza od dawna jest uważana za formację odchodzącą do przeszłości, a zastrzeżony dla niej obszar władztwa administracyjnego zmniejsza się na rzecz niewładczych form działania ${ }^{13}$. W doktrynie wskazuje się wiele przyczyn takiego stanu rzeczy, m.in. wynikające ze swoistego "zachwytu" gospodarką rynkową przekonanie o lepszej efektywności i elastyczności umowy ${ }^{14}$. W tym miejscu warto przytoczyć również interesujący pogląd B. Jaworskiej-Dębskiej, zgodnie z którym obserwować można pojawienie się $\mathrm{w}$ administracji woli zejścia $\mathrm{z}$ koturnów, z piedestału władzy, i przyjęcia postawy partnerskiej wobec obywatela,

${ }^{9}$ D. Kijowski, Ucieczka administracji publicznej w sferę prawa cywilnego, w: Współczesne zagadnienia prawa i procedury administracyjnej. Ksiegga jubileuszowa dedykowana Prof. zw. dr. hab. Jackowi M. Langowi, pod red. M. Wierzbowskiego, J. Jagielskiego, A. Wiktorowskiej, E. Stefańskiej, Warszawa 2009, s. 115-136.

${ }^{10}$ Odnośnie do władczych prawnych form działania por. K. Ziemski, Indywidualny akt administracyjny jako forma prawna działania administracji, Poznań 2005, s. 15-76, 118-137 i n., 516 i n.; W. Chróścielewski, op. cit., passim. Wymienieni przedstawiciele doktryny wskazują, że władztwo to możliwość wiążącej konkretyzacji praw i obowiązków adresata działań organu administracji publicznej, których wykonywanie, w przypadku gdy treścią tej konkretyzacji było nałożenie obowiązków, obwarowane jest możliwością zastosowania środków przymusu państwowego. Z nowszej literatury zob. R. Godlewski, H. Kisilowska, Przenikanie się prawa administracyjnego i prawa cywilnego na przykładzie gospodarki nieruchomościami i prawa budowlanego, w: A. Doliwa, S. Prutis, Wypieranie prawa administracyjnego przez prawo cywilne, seria Kryzys prawa administracyjnego, pod red. D. Kijowskiego, P.J. Suwaj, t. 3, Warszawa 2012, s. 39-44: por. także J. Boć, Dziatalność konsensualna (dwustronna i wielostronna), w: Prawne formy działania administracji, s. 237; J. Łukasiewicz, K. Kłosowska, Słowo o przyrzeczeniu administracyjnym, w: Umowy $w$ administracji, s. 100.

${ }^{11} \mathrm{H}$. Knysiak-Molczyk, Inne formy działania administracji publicznej, w: Koncepcja systemu prawa administracyjnego..., s. 492.

${ }^{12}$ Ustawa z dnia 23 IV 1964 r. - Kodeks cywilny (tekst jedn. Dz.U. 2014, poz. 121 ze zm.), dalej "k.c." lub „Kodeks cywilny”.

${ }^{13}$ E. Cisowska-Sakrajda, Ustalenia co do sposobu załatwienia sprawy w postępowaniu mediacyjnym, w: Umowy w administracji, s. 457. Autorka przez formy niewładcze rozumie takie formy, które zakładają rodzaj równowagi sił między obywatelem a administracją oraz zmniejszają poczucie nadmiernej zależności obywatela od administracji (zob. ibidem).

${ }^{14}$ Zob. np. A. Kubiak, Perspektywy rozwoju form konsensualnych w polskim prawie administracyjnym, w: Umowy w administracji, s. 77 i n. 
a także innego podmiotu administrowanego ${ }^{15}$. W doktrynie wzrost zastosowania przez podmioty administracji publicznej prawnej formy działania, jaką jest umowa, określa się mianem kontraktualizacji ${ }^{16}$, konsensualizacji, prywatyzacji, czy też konwencjonalizacji administracji publicznej ${ }^{17}$. Jako że współczesna administracja do wykonywania coraz bardziej złożonych zadań w dynamicznie zmieniającym się otoczeniu społecznym i ekonomicznym potrzebuje elastycznych prawnych form działania, do zjawiska tego w ogólności należy się odnieść pozytywnie - stanowi ono bowiem przejaw modernizacji współczesnego prawa administracyjnego. $\mathrm{W}$ obliczu tendencji związanych $\mathrm{z}$ postępującą globalizacja, digitalizacją oraz instrumentalizacją współczesnego prawa stosowanie elastycznych prawnych form działania administracji wydaje się nieuniknione.

Jak wywodzi D. Kijowski, ze względu na swój dwustronny charakter umowa najlepiej nadaje się do wykorzystania tam, gdzie niezbędna jest elastyczność regulacji stosunków między administracją a jednostka, ponieważ pozwala na uwzględnienie różnorodnych i zmieniających się w czasie okoliczności ${ }^{18}$. Ponadto w doktrynie wskazuje się, że umowa, jako typowy "instrument” gospodarki rynkowej, lepiej nadaje się do wykorzystania w procesie oddziaływania państwa na przedsiębiorców w ramach realizacji polityki gospodarczej państwa, gwarantując, że

${ }^{15}$ B. Jaworska-Dębska, op. cit., s. 14; podaję za: J. Boć, Działalność konsensualna..., s. 239; podobnie w doktrynie niemieckiej H. Bauer wskazuje na trend "państwa kooperującego": „Der Staat steigt vom hoheitlich-hoheitsvollen Podest des einseitig Anweisenden herab, er Tritt auf die Ebene des Austausches von Informationen und Leistungen und der Verbindung zu abgestimmten Handeln" (H. Bauer, Entwicklungslinien der Vertragsrechtslehre, w: Grundlagen des Verwaltungsrecht, Bd. 2: Informationsordnung, Verwaltungsverfahren, Handlungsformen, Hrsg. von W. Hoffmann-Riem, E. Schmidt-Assmann, A. Voßkuhle, München 2012, s. 1266.

${ }^{16}$ Por. A. Modrzejewski, Kontraktualizacja w globalnym i europejskim prawie administracyjnym, w: Wypieranie..., s. 39-44.

${ }_{17}$ A. Piszcz, Partnerstwo publiczno-prywatne jako wyraz kontraktualizacji administracji publicznej, w: Umowy w administracji, s. 255 i n.

${ }^{18}$ D. Kijowski, Umowy w administracji publicznej, w: Podmioty administracji publicznej i prawne formy ich działania. Studia i materiaty z konferencji naukowej poświęconej jubileuszowi 80-tych urodzin Profesora Eugeniusza Ochendowskiego, Toruń 2005, s. 282 i n. Autor dalej przywołuje poglądy przedstawicieli niemieckiej i austriackiej doktryny prawa: Z. Giacometti, Allgemeinez Lehren der rechtsstaatlichen Verwaltungsrecht, Zürich 1960, s. 95; E. Forsthoff, Lehrbuch des Verwaltungsrecht, Bd. 1, Berlin-München 1966, s. 477; L.K. Adamovich, B.C. Funk, Allgemeines Verwaltungsrecht, Wien-New York 1980, s. 155 i n. Podobnie A. Miruć, Umowy w działaniach administracji pomocy społecznej, w: Umowy w administracji, s. 347-348. 
rezultaty jej zastosowania zapewnią w najlepszym stopniu uwzględnienie praw ekonomicznych i zasad rachunku ekonomicznego ${ }^{19}$.

W celu realizacji różnorodnych przypisanych administracji zadań wymagane jest stosowanie odpowiednich narzędzi, zapewniających swobodę i elastyczność działania, co według ustawodawcy może być zagwarantowane przez stosowanie umowy - tendencja ta znajduje odzwierciedlenie w stanowionym prawie ${ }^{20}$.

Warto też już na początku rozważań dotyczących umowy stosowanej w administracji zwrócić uwagę na aspekt proceduralny. Mianowicie, co do zasady, k.p.a. nie przewiduje możliwości załatwienia sprawy w innej prawnej formie działania niż indywidualny akt administracyjny ${ }^{21}$. Ustawodawca polski, odpowiadając na coraz większe zapotrzebowanie na elastycznie działającą administrację publiczna, wprowadza do przepisów prawa materialnego coraz częściej możliwość stosowania niewładczych form działania, stosując bądź to szczególne typy umów ${ }^{22}$, bądź umowy zdefiniowane w Kodeksie cywilnym, które zastosowane przez organ administracji publicznej nabierają cech umowy publicznej ${ }^{23}$. Ponadto $\mathrm{w}$ zakresie proceduralnym ustawodawca ustanawia szczegółowe cywilne tryby postępowania lub odsyła do Kodeksu cywilnego.

Można zatem wysunąć wniosek, że przepisy prawa proceduralnego (w szczególności k.p.a.) nie odpowiadają potrzebom nowoczesnej administracji. Ustawodawca powinien rozważyć, czy nie wprowadzić do k.p.a. przepisów dotyczących umowy administracyjnej ${ }^{24}$ - powyższe zagadnienie będzie przedmiotem rozważań w następnych częściach artykułu.

${ }^{19}$ D. Kijowski, Umowy..., s. 282; ponadto idem, Umowa jako forma działania administracji, „Zeszyty Naukowe Uniwersytetu Warszawskiego Filii w Białymstoku” 1987, t. 13, z. 57, s. 7-54.

${ }^{20} \mathrm{~J}$. Wyporska-Frankiewicz, Publicznoprawne formy działania administracji o charakterze dwustronnym, Warszawa 2010, s. 227; por. B. Jaworska-Dębska, op. cit., s. 13 i n.; H. Knysiak-Molczyk, op. cit., s. 491 i n.

${ }^{21}$ Por. R. Suwaj, Umowy w zarzadzaniu pasem drogowym, w: Umowy w administracji, s. $411 \mathrm{i} \mathrm{n.}$

${ }^{22}$ R. Suwaj wskazuje tutaj przykładowo na umowę szkoleniową z ustawy o promocji zatrudnienia i instytucjach rynku pracy.

${ }^{23}$ R. Suwaj, op. cit., s. 411 i n.

${ }^{24}$ T. Rabska, Kontrakt wojewódzki - forma działania administracji publicznej w strukturach zdecentralizowanych, w: Instytucje wspótczesnego prawa administracyjnego. Księga jubileuszowa Profesora zw. dra hab. J. Filipka, pod red. I. Skrzydło-Niżnik, Kraków 2001, s. 612 i n. 
Polska regulacja w zakresie prawa cywilnego (art. 1 k.c.) jest niezwykle elastyczna, do czego należy odnieść się z aprobata, bowiem, jak wskazuje D. Kijowski, nie istnieje taka sfera, czynności czy zachowania, które nie mogłyby się stać przedmiotem regulacji umowy prawa cywilnego ${ }^{25}$. Jednakże należy zwrócić uwagę, że przepisy Kodeksu cywilnego nie przewidują możliwości realizowania zadań publicznych przy zastosowaniu umów ${ }^{26}$. W konsekwencji w Kodeksie cywilnym nie zawarto przedmiotowych regulacji, a takich kompetencji należy poszukiwać w ustawach szczególnych.

Umowa cywilnoprawna jest czynnością konsensualną - dochodzi do skutku w wyniku złożenia wzajemnych oświadczeń woli dwóch lub więcej stron. Oświadczenie woli należy tak tłumaczyć, jak tego wymagają ze względu na okoliczności, w których złożone zostało, zasady współżycia społecznego oraz ustalone zwyczaje (art. 65 § 1 k.c.). $W$ umowach należy raczej badać, jaki był zgodny zamiar stron i cel umowy, aniżeli opierać się na jej dosłownym brzmieniu (art. 65 § 2 k.c.). Z zastrzeżeniem wyjątków w ustawie przewidzianych, wola osoby dokonującej czynności prawnej może być wyrażona przez każde zachowanie się tej osoby, które ujawnia jej wolę w sposób dostateczny, w tym również przez ujawnienie tej woli w postaci elektronicznej (oświadczenie woli) (art. 60 k.c.).

Umowa cywilnoprawna jest zawierana zgodnie z zasadą swobody umów, co czyni ją elastyczną prawną formą działania administracji publicznej. Rozwijając zagadnienie elastyczności umów wykorzystywanych w administracji, B. Jaworska-Dębska, odwołując się do art. $353^{1}$ k.c., zgodnie z którym strony zawierające umowę mogą ułożyć stosunek prawny według swego uznania, byleby jego treść lub cel nie sprzeciwiały się właściwości (naturze) stosunku, ustawie ani zasadom współżycia społecznego, stwierdza, że podmiot administracji publicznej, zawierając umowę cywilnoprawną, działa w ramach swobody umów ${ }^{27}$. Z drugiej strony w przypadku umów zawieranych przez administrację owa

${ }^{25}$ D. Kijowski, Umowy..., s. 282 i n.

${ }^{26}$ Ibidem.

${ }^{27}$ B. Jaworska-Dębska, op. cit., s. 19. Powyższy pogląd nie jest jednolicie przyjmowany w doktrynie. Przykładowo, inaczej S. Dudzik, Działalność gospodarcza samorzadu terytorialnego, Kraków 1998, s. 184 i n., oraz L. Kieres, Prawa podmiotowe w działalności gospodarczej w świetle orzecznictwa Trybunału Konstytucyjnego. Zdolność do skargi konstytucyjnej, w: Swoistość procedur publicznego prawa gospodarczego, pod red. B. Popowskiej, Poznań 2013, s. 20 i n. 
swoboda zawierania umów przedstawia się nieco inaczej niż w przypadku "klasycznych" umów cywilnoprawnych ${ }^{28}$.

Niejednokrotnie bowiem obywatel musi zawrzeć umowę z podmiotem administracji, ponieważ nie może on uzyskać świadczenia od innego podmiotu ${ }^{29}$. To wszystko powoduje bardzo nierówną pozycję stron stosunku prawnego, ze zdecydowaną przewagą administracji ${ }^{30}$. Dochodzi do sytuacji, w której ocena, czy mamy do czynienia ze stosunkiem cywilnoprawnym czy też administracyjnoprawnym, może sprawić trudności ${ }^{31}$. Powyższe nie oznacza oczywiście, że nie zachodzi w tym przypadku autonomia woli stron, a także że strony nie są równe. Przedmiotem rozważań jest kwestia takiego uregulowania stosunków prawnych między stronami, iż faktycznie dochodzi do przewagi jednej ze stron.

Na tym tle powstaje pytanie, czy regulacja stosunków prawnych między administracją a obywatelem zapewnia równość jej stron ${ }^{32}$. Zdaniem A. Kubiak niezależnie od rodzaju umowy w wielu przypadkach nie da się wyeliminować elementu przewagi podmiotu publicznego nad jej kontrahentem ${ }^{33}$. W pewnych sytuacjach równorzędność stron umowy będzie fikcją, a zasada swobody kontraktowania pozostanie bez znaczenia w obliczu skutków rezygnacji przez obywatela z zawarcia umowy - np. nie otrzyma on oczekiwanego świadczenia ${ }^{34}$. Podkreśla się, że w takich przypadkach będziemy mieli do czynienia z większym stopniem "władczości" organu działającego w formie umowy cywilnoprawnej, niż gdy działa on przy użyciu aktu administracyjnego indywidualnego ${ }^{35}$. Podmiot administracji, np. odmawiając udzielenia pomocy publicznej, nie będzie podlegał kontroli organu wyższego stopnia, uruchamianej na żądanie strony, ani też sądowej kontroli legalności działalności administracji ${ }^{36}$.

${ }^{28}$ Piszę o tym w: Granice swobody zawierania przez jednostki samorzadu terytorialnego umów, o których mowa w art. 3 ustawy o gospodarce komunalnej, „Kwartalnik Prawo-Społeczeństwo-Ekonomia" 2017, nr 2, s. 71-85.

${ }^{29}$ Por. A. Czarkowska, Umowy adhezyjne w administracji publicznej, w: Umowy w administracji, s. 47 i n.

${ }^{30}$ Ibidem.

${ }^{31}$ Ibidem.

${ }^{32}$ A. Kubiak, op. cit., s. 80.

${ }^{33}$ Ibidem.

${ }^{34}$ Por. ibidem.

${ }^{35}$ Ibidem.

${ }^{36}$ W. Chróścielewski, op. cit., s. 57-58. 
Należy wskazać, że poddanie wszelkich sporów z umów cywilnoprawnych kognicji sądownictwa powszechnego, powołanego do rozstrzygania spraw z zakresu prawa prywatnego, powoduje, że zakładana $\mathrm{w}$ umowach cywilnoprawnych równość stron stawia w zdecydowanie trudniejszej sytuacji procesowej kontrahenta administracji ${ }^{37}$.

\section{Umowa administracyjna}

Powyżej wykazano, że bezspornie jedną z prawnych form wykonywania zadań publicznych jest umowa znana prawu cywilnemu ${ }^{38}$.

Należy podkreślić, że, co do zasady, umowy cywilnoprawne służą ochronie interesu obu stron cywilnoprawnego stosunku prawnego. Inaczej jednak sprawa wygląda w zakresie ochrony interesów w przypadku, gdy jedną ze stron umowy jest podmiot administracji publicznej. J. Boć wskazał, że w razie gdy umowa zawierana jest między organem administracji publicznej a podmiotem spoza administracji publicznej, ekwiwalentność praw i obowiązków układa się w sposób szczególny, ponieważ organ administracji ani nie realizuje, ani nie chroni własnych interesów, gdyż ich nie ma ${ }^{39}$. Jak podnosi dalej autor, organ administracji publicznej stosuje po prostu prawo, bo do tego został powołany, wyposażony w kompetencję (zawarcia umowy z podmiotem zewnętrznym) i obciążony publicznoprawnym obowiązkiem jej realizacji, a więc wyłącznie dla potrzeb i w ochronie interesu publicznego nie tylko wtedy, gdy podejmuje działania władcze, ale i wtedy, gdy wchodzi w obrębie przydanych mu uprawnień w umowę cywilnoprawną ${ }^{40}$.

Charakterystyczne dla umowy cywilnej jako prawnej formy działania administracji jest to, że jej treść i sposób wykorzystania jest w znacznym stopniu normowany przepisami prawa administracyjnego ${ }^{41}$. Powyższe stwierdzenie dotyczy istotnej części umów zawieranych przez podmioty administracji publicznej. Biorąc pod uwagę stopień ingerencji norm prawa administracyjnego w treść i formę umowy cywilnej, można

\footnotetext{
${ }^{37}$ Ibidem.

${ }^{38} \mathrm{~K}$. Ziemski, Akt administracyjny i jego alternatywy, w: Koncepcja systemu prawa administracyjnego..., s. 415-426.

39 J. Boć, Działalność konsensualna..., s. 252 i n.; idem, O umowie administracyjnej, w: Umowy w administracji, s. 31 i n.

${ }^{40}$ Ibidem.

${ }^{41}$ Ibidem, s. 242-243 i n.
} 
dokonać zróżnicowania takich umów ${ }^{42}$. Kryterium ingerencji norm prawa publicznego w treść umowy cywilnoprawnej może posłużyć do wyróżnienia spośród stosowanych przez administrację umów różnych ich typów, poczynając od takich, które w przeważającej części regulowane są przepisami prawa cywilnego, a kończąc na takich, w których zdecydowaną przewagę mają elementy o charakterze administracyjnym ${ }^{43}$.

Warto wskazać, że często w doktrynie traktuje się umowy zawierane przez administrację jako należące do zakresu prawa cywilnego. Należy zgodzić się z J. Bociem, że nacisk na traktowanie wszystkich przysługujących administracji publicznej umów jako w pełni cywilnoprawnych powinien natrafić na pewien opór ${ }^{44}$. Jak podnoszą W. Taras i A. Wróbel, przewidziane $\mathrm{w}$ aktach normatywnych formy umowne, których jedną ze stron jest organ administracji, arbitralnie zostawały "przywłaszczane" przez prawo cywilne i jego naukę, chociaż ich przynależność do tej gałęzi prawa nie była i nie jest oczywista ${ }^{45}$. Funkcje takich umów, ich sposób zawierania, a także ich związek z wykonywaniem przez administrację zadań publicznych przemawiałyby raczej za zaliczeniem takich prawnych form działania administracji do kategorii umów o charakterze publicznym niż do umów cywilnych ${ }^{46}$. Nadto autorzy wskazuja, że bezpośredni związek funkcji tych umów jako form realizacji ustawowych zadań administracji z pełnieniem przez strony wspomnianych umów funkcji o charakterze publicznym, zwłaszcza w sferze administracji świadczącej, sytuuje je raczej poza obszarem prawa cywilnego ${ }^{47}$.

\subsection{Koncepcja umowy administracyjnej w polskiej doktrynie prawa}

Biorąc pod uwagę umowę jako prawną formę działania administracji i uwzględniając wcześniejsze rozważania dotyczące umowy, jako podstawową klasyfikację należy przyjąć podział na umowy prawa cywilnego

\footnotetext{
${ }^{42}$ Ibidem.

${ }^{43}$ Por. W. Chróścielewski, op. cit., s. 53 i n.; J. Wyporska-Frankiewicz, op. cit., s. 242243 i n.

${ }^{44}$ J. Boć, Działalność konsensualna..., s. 256 i n.

${ }^{45}$ W. Taras, A. Wróbel, W sprawie jednolitej koncepcji umów publicznych, w: Prawo administracyjne w okresie transformacji ustrojowej, pod red. E. Knosali, A. Matana, G. Łaszczycy, Kraków 1999, s. 123, cyt. za: J. Boć, Działalność konsensualna..., s. 256.

${ }^{46}$ Ibidem, s. 122 i n.

${ }^{47}$ Ibidem, s. 123.
} 
i publicznego ${ }^{48}$. Powyższy podział wynika z przyjętego w klasyfikacji prawnych form działania podziału czynności prawnych podejmowanych przez administrację na czynności publiczno- i prywatnoprawne ${ }^{49}$. Podkreślić jednak należy, że możliwość zawierania umów publicznoprawnych przez administrację w związku z realizacją zadań publicznych budziła i wciąż budzi kontrowersje ${ }^{50}$.

Z rozważań dotyczących wykorzystywania umowy w działalności administracji (w zakresie realizacji jej zadań) wynika niezbicie, że umowa, za pomocą której administracja publiczna realizuje zadania publiczne, ma szczególne cechy. $Z$ analizy przepisów ustawowych wynika, że może to być zarówno klasyczna umowa cywilnoprawna, jak i umowa o zasadniczo specyficznych cechach. Te specyficzne cechy powoduja, że istnieje potrzeba wyróżnienia i omówienia kategorii umów określanych w doktrynie jako umowy administracyjne bądź umowy publicznoprawne. Propozycję uporządkowania pojęciowego sformułował J. Boć, wskazując, że wśród umów publicznoprawnych wyróżnia się porozumienie o stronach $\mathrm{z}$ administracji publicznej i umowę administracyjna, w której jedną stroną jest podmiot $\mathrm{z}$ administracji publicznej, a drugą stroną podmiot spoza tej administracji ${ }^{51}$.

W doktrynie nie ustalono jednak, czy w sytuacji, kiedy administracja posługuje się umową prawa cywilnego, która została istotnie zmodyfikowana przez regulacje administracyjnoprawne, mamy do czynienia $\mathrm{z}$ nową kategorią umowy, zwaną w doktrynie prawa polskiego umową administracyjna, czy też nadal z umową cywilnoprawną. W świetle braku prawnej regulacji umów administracyjnych powyższa kwestia jest przedmiotem ciągłej dyskusji naukowej. Jak podnosi J. Boć, pomimo przydatności umowy cywilnoprawnej w kształtowaniu stosunków gospodarczych i społecznych, funkcjonuje w doktrynie polskiej i wielu

${ }^{48}$ A. Miruć, Umowy w działaniach administracji..., s. 346.

${ }^{49}$ Por. W.L. Jaworski, Nauka prawa administracyjnego, Warszawa 1924, s. 78; S. Kasznica, Polskie prawo administracyjne, Poznań 1946, s. 112, cyt. za: K. Ziemski, Indywidualny akt administracyjny..., s. 113.

${ }^{50}$ Por. L. Zacharko, S. Nitecki, Umowa jako forma prywatyzacji zadań publicznych w świetle ustawy o pomocy społecznej, w: Umowy w administracji, s. 447 i n.

${ }^{51}$ J. Boć, Działalność konsensualna..., s. 269. Należy przy tym zauważyć, że takie rozumienie umowy administracyjnej po części będzie odwoływać się do niemieckiej teorii. Mianowicie w wypadku porozumienia administracyjnego będziemy mieli do czynienia z koordynacyjną umową administracyjną w rozumieniu § 54 niemieckiej ustawy o postępowaniu administracyjnym, natomiast w przypadku umowy zawieranej między podmiotem administracji a jednostką wystąpi subordynacyjna umowa administracyjna. 
innych państw europejskich pogląd o konieczności wyodrębnienia kolejnej prawnej formy działania, jaką jest umowa administracyjna ${ }^{52}$. A zatem oprócz klasycznej umowy w administracji ${ }^{53}$ konieczne jest omówienie umowy określanej w doktrynie prawa polskiego jako umowa administracyjna.

Umowa administracyjna od dawna jest przedmiotem zainteresowania doktryny polskiego prawa publicznego i powstały na jej temat wartościowe i wiele wnoszące do nauki prace ${ }^{54}$. Pierwsze $\mathrm{w}$ tym zakresie były publikacje J.S. Langroda ${ }^{55}$. Autor wskazał, że taka umowa w polskim prawie mogłaby być przydatna ${ }^{56}$. Umowa publicznoprawna była też przedmiotem zainteresowania J. Starościaka ${ }^{57}$. Autor ten rozwiną koncepcję porozumień administracyjnych ${ }^{58}$. Tak jak wskazano

52 Por. J. Boć, Działalność konsensualna..., s. 264 i n.

${ }^{53}$ Doktryna niemiecka wspomina o prawie umów w administracji - Verwaltungsprivatrecht, dotyczącym umów cywilnoprawnych, którymi posługuje się administracja, zob. D. Ehlers, Verwaltung in Privatrechtsform, Berlin 1984, s. 607.

${ }^{54}$ Zob. np.: M. Wilbrandt-Gotowicz, Umowa jako forma działania administracji publicznej (w świetle pogladów J.S. Langroda), w: Teoria instytucji prawa administracyjnego. Ksiega pamiatkowa Profesora Jerzego Stefana Langroda, pod red. J. Niczyporuka, Lublin 2011, s. 441-453; M. Rypina, M. Wierzbowski, Umowa z organem w postępowaniu administracyjnym, „Państwo i Prawo” 2010, z. 4, s. 15-27; J. Wyporska-Frankiewicz, op. cit.; D. Kijowski, Umowa administracyjna w części ogólnej polskiego prawa administracyjnego, w: Nowe problemy badawcze w teorii prawa administracyjnego, pod red. J. Bocia, A. Chajbowicza, Wrocław 2009, s. 283-292; J. Boć, O umowie administracyjnej...; A. Kubiak, op. cit., s. 77-88; A. Panasiuk, Umowa publicznoprawna, "Państwo i Prawo" 2008, z. 2, s. 18-31; Z. Cieślik, Umowa administracyjna w państwie prawa, Warszawa 2004, s. 122; B. Dolnicki, Umowa publicznoprawna w prawie niemieckim, „Państwo i Prawo” 2001, z. 3, s. 79-86; T. Rabska, op. cit., s. 601-612; W. Taras, A Wróbel, op. cit., s. 115-125; S. Biernat, Prywatyzacja zadań publicznych. Problematyka prawna, Warszawa-Kraków 1994, s. 155; D. Kijowski, W sprawie charakteru prawnego umów zawieranych przez organy administracji, „Państwo i Prawo" 1987, z. 6, s. 77-87; J. Filipek, Stosunek administracyjnoprawny, Kraków 1968, s. 102-104; M. Kania, Umowa..., s. 519-543; A. Krawczyk, Umowa administracyjna w demokratycznym państwie prawnym - w poszukiwaniu modelu regulacji prawnej, "Zeszyty Naukowe Sądownictwa Administracyjnego" 2017, nr 6, s. 7-25.

55 J.S. Langrod, Instytucje prawa administracyjnego: zarys części ogólnej, Kraków 1948, Reprint: Kraków 2003, s. 310 i n.

${ }^{56}$ Por. J. Boć, Działalność konsensualna..., s. 265.

${ }^{57}$ P. Przybysz, Umowa jako forma działania administracji w świetle pogladów Profesora Jerzego Starościaka, w: Umowy w administracji, s. 127-128.

${ }^{58}$ J. Starościak, System prawa..., s. 89 i n.; idem, Prawo administracyjne, Warszawa 1977, s. 247 i n. Porozumienie administracyjne doczekało się niezwykle bogatej literatury. Jest to czynność prawna o charakterze konsensualnym, która jest zawierana między podmiotami administracji publicznej, niezależnymi względem siebie, a więc takimi, które nie znajdują się w relacjach nadrzędności lub podporządkowania. Porozumienie 
powyżej, słuszne jest (za J. Bociem) zakwalifikowanie porozumienia administracyjnego, obok umowy administracyjnej, jako drugiego typu umowy publicznoprawnej.

\subsection{Umowa administracyjna w prawie niemieckim}

Umowa administracyjna w prawie niemieckim była wielokrotnie przedmiotem analizy doktryny polskiego prawa publicznego, zwłaszcza w kontekście ewentualnego wprowadzenia tej instytucji prawnej do polskiego systemu prawnego. $W$ tym świetle istotne są spostrzeżenia B. Popowskiej, zwłaszcza na przykładzie udzielania pomocy publicznej przedsiębiorcom. Praktyka działania administracji gospodarczej w Niemczech wykształciła określony wzorzec prawnego rozwiązywania problemów dotyczących pytań, np. odnoszących się do prawa pomocy publicznej ${ }^{59}$. W sprawach unormowanych publicznoprawnymi przepisami prawa materialnego, a więc w sprawach finansowego wspierania przedsiębiorczości, oprócz indywidualno-konkretnych rozstrzygnięć w Republice Federalnej Niemiec (RFN) zaczęto stosować umowy jako prawne formy działania administracji ${ }^{60}$.

Instytucja umowy administracyjnej została wprowadzona do niemieckiego porządku prawnego federalną ustawą o postępowaniu administracyjnym w $1976 \mathrm{r} \cdot{ }^{61}$ Niemiecka ustawa wyróżnia dwa rodzaje umowy administracyjnej - koordynacyjnoprawną i subordynacyjnoprawną ${ }^{62}$. Strony umów koordynacyjnoprawnych (co do zasady

dochodzi do skutku przez złożenie oświadczeń. Jego przedmiotem mogą być wyłącznie zadania i kompetencje z zakresu administracji publicznej. Jego istotą jest przeniesienie zadań i kompetencji przypisanych jednemu podmiotowi administracji publicznej na inny podmiot administracji publicznej. Por. J. Starościak, System prawa..., s. 89 i n.; J. Wyproska-Frankiewicz, op. cit., s. 135-219; B. Wach, S. Wach, Umowy w funkcjonowaniu administracji publicznej a sytuacja prawna jednostki (obywatela), w: Umowy w administracji, s. 196-198; M. Róg, Porozumienia administracyjne w działalności Komendanta Głównego Policji, w: Umowy w administracji, s. 363-369.

${ }^{59}$ B. Popowska, Decyzja i umowa..., s. 113.

${ }^{60}$ A. Bleckmann, Zum gerichtlichen Schutz des öffentlichen Finanzinteresses bei der Vergabe von Subventionen und öffentlichen Aufträgen, "Jahrbuch des öffentlichen Rechts" 2005, Nr. 53, s. 285-309; Z. Cieślik, op. cit., s. 63.

${ }^{61}$ Verwaltungsverfahrensgesetz, ustawa z dnia 25 V 1976 r., Bundesgesetzblatt I, s. 153 (dalej „VwVfG").

${ }^{62}$ H. Bauer, Bausteine für eine Lehre vom Verwaltungsvertrag, w: Grundlagen..., s. 1321 i n.; Z. Cieślik, op. cit., passim; J. Wyporska-Frankiewicz, op. cit., s. 234. 
podmioty administracji publicznej) są względem siebie równorzędne (zarówno w momencie zawarcia umowy, jak i w czasie jej realizacji), podczas gdy pozycja stron umowy subordynacyjnoprawnej nie jest równorzędna ${ }^{63}$. Umowy koordynacyjne przypominają porozumienia administracyjne w prawie polskim, ponieważ sa, co do zasady, zawierane pomiędzy podmiotami administracji publicznej. Do analizy naukowej dotyczącej stosunków administracji z obywatelem zastosowanie powinny znaleźć rozważania dotyczące umowy subordynacyjnoprawnej ${ }^{64}$.

Umowy subordynacyjnoprawne zawierane są między podmiotami, które - gdy nie ma kontraktowego między nimi powiązania - pozostają w stosunkach podporządkowania-nadrzędności ${ }^{65}$. W momencie zawarcia umowy podmiot nadrzędny rezygnuje ze swej uprzywilejowanej pozycji, również bowiem na gruncie publicznego prawa kontraktowego obowiązuje zasada równości stron ${ }^{66}$. Umowy subordynacyjnoprawne mogą zastępować akt administracyjny, zawierać zobowiązanie organu do wydania określonego aktu lub nie pozostawać w jakimkolwiek związku z jakimkolwiek aktem administracyjnym ${ }^{67}$. Umowa subordynacyjna może określać prawa bądź obowiązki o charakterze publicznoprawnym i w ten sposób zastępuje akt administracyjny, różniąc się od niego o tyle, że powstaje ona w drodze negocjacji i konsensusu między organem administracji a obywatelem ${ }^{68}$.

Definicję legalną umowy publicznoprawnej zamieścił federalny ustawodawca niemiecki w przepisie § $54 \mathrm{VwvfG}$, który stanowi, że "stosunek prawny z zakresu prawa publicznego może być w drodze umowy

${ }^{63}$ Por. J. Wyporska-Frankiewicz, op. cit., s. 234.

${ }^{64}$ B. Popowska, Decyzja i umowa..., s. 113. Autorka dodaje, że w Niemczech w ostatnich latach są dyskutowane propozycje zmian regulujących umowy administracyjne. W celu włączenia w szerokim zakresie podmiotów prywatnych w wypełnianie zadań publicznych postuluje się wprowadzenie do VwVfG nowego typu umowy - umowy kooperacji (Kooperationsvertrag), zob. H. Schmitz, Die Verträge sollen sicherer werden - zur Novellierung der Vorschriften über den öffentlich-rechtlichen Vertrag, Deutsches Verwaltungsblatt 2005, s. 18, cyt. za: B. Popowska, Decyzja i umowa... Por. też: H. Bauer, Entwicklungslinien..., s. 1271; H. Pünder, Kooperation statt Konfrontation - Zur der Kontrakte zwischen Politik und Verwaltung im Rahmen des Neuen Steuerungsmodell, "Die Öffentliche Verwaltung" 1998, H. 2, s. 63-71.

${ }^{65}$ B. Popowska, Decyzja i umowa..., s. 113.

${ }^{66}$ Ibidem.

${ }^{67}$ Z. Cieślik, op. cit., s. 43.

${ }^{68}$ Por. A. Śledzińska, Umowy administracyjne w prawie i praktyce innych krajów, w: Umowy..., s. 188-189. Ciekawe jest spostrzeżenie tej autorki, zgodnie z którym w praktyce administracji niemieckiej występuje coraz częstsze stosowanie stypizowanych form umownych, co w praktyce zbliża je do aktu administracyjnego (ibidem). 
zawarty, zmieniony lub zniesiony (umowa publicznoprawna), o ile nie stoją temu na przeszkodzie przepisy prawa. W szczególności organ administracyjny może zamiast wydawania aktu administracyjnego zawrzeć umowę publicznoprawną z podmiotem, do którego kierowany byłby akt administracyjny" 69 .

Jak wskazuje D. Kijowski, pod pojęciem umowy publicznoprawnej rozumie się $\mathrm{w}$ doktrynie niemieckiego prawa publicznego zarówno umowy zawierane między samymi organami administracji publicznej, jak i umowy zawierane między organami administracji a podmiotami prywatnymi, a także nawet umowy zawierane wyłącznie pomiędzy podmiotami prywatnymi (np. w sprawie rozłożenia ciążących na nich obowiązków publicznoprawnych), istotne jest bowiem uregulowanie taką umową stosunku z zakresu prawa administracyjnego ${ }^{70}$.

W literaturze niemieckiej przyjęto, że do zawarcia umowy administracyjnej nie jest niezbędna wyraźna podstawa prawna - wystarczy, że przepisy prawa jej nie zakazują ${ }^{71}$. Jest to nawiązanie do tzw. zasady swobody wyboru prawnej formy działania przez administrację, która została opracowana przez niemiecką doktrynę $e^{72}$. Zasada swobody wyboru prywatnoprawnej formy działania administracji legła u podstawy wprowadzenia do prawa niemieckiego umowy administracyjnej ${ }^{73}$. Z kolei moc wiążąca umów publicznoprawnych wyprowadzana jest z obowiązywania - także na obszarze prawa administracyjnego, zasady pacta

${ }^{69}$ W oryg. „Ein Rechtsverhältnis auf dem Gebiet des öffentlichen Rechts kann durch Vertrag begründet, geändert oder aufgehoben werden (öffentlich-rechtlicher Vertrag), soweit Rechtsvorschriften nicht entgegenstehen. Insbesondere kann die Behörde, anstatt einen Verwaltungsakt zu erlassen, einen öffentlich-rechtlichen Vertrag mit demjenigen schließen, an den sie sonst den Verwaltungsakt richten würde", tłumaczenie zob. w: B. Dolnicki, op. cit., s. 79.

${ }^{70}$ D. Kijowski, $W$ sprawie charakteru prawnego umów..., s. 82. Autor wskazuje w tym zakresie następującą literaturę niemiecką: E. Forsthoff, Lehrbuch der Verwaltungsrecht, s. 266 i n.; F. Mayer, Allgemeines Verwaltungsrecht, Stuttgart 1972, s. 96 i n.; T. Öhlinger, Allgemeines Verwaltungsrecht, Stuttgart 1972, s. 11 i n.; H.U. Erichsen, W. Martens, Das Verwaltungshandeln, w: iidem, Allgemeines Verwaltungsrecht, Berlin-New York 1977, s. $212 \mathrm{i} \mathrm{n.}$

${ }^{71}$ Por. D. Kijowski, W sprawie charakteru prawnego umów..., s. 82 i n.; J. Wyporska-Frankiewicz, op. cit., s. 234-235.

${ }^{72}$ M. Bullinger, Vertrag und Verwaltungsakt, Stuttgart 1962, s. 46 i n., cyt. za: B. Tanneberg, Die Zweistufentheorie, Berlin 2011, s. 71; C. Pestalozza, Formenmissbrauch des Staates, München 1973; B. Kempen, Die Formenwahlfreiheit der Verwaltung. Die öffentliche Verwaltung zwischen öffentlichen und privatem Recht, München 1989.

${ }^{73}$ E. Gurlit, Verwaltungsvertrag und Gesetz. Eine vergleichende Untersuchung zum Verhältnis von vertraglicher Bindung und staatlicher Normsetzungsautorität, Tübingen 2000, s. 21 i n. 
sunt servanda ${ }^{74}$. Przedstawiciele doktryny niemieckiej, nawet ci, którzy wskazywali na zagrożenia związane $z$ dopuszczeniem tej instytucji, podkreślają zwykle praktyczną użyteczność i skuteczność załatwiania spraw w drodze pertraktacji prowadzonych przez organy władzy i obywateli państwa ${ }^{75}$.

W doktrynie niemieckiej można spotkać pogląd, zgodnie z którym w sytuacji gdy stosunki tworzone, przekształcane bądź też znoszone przez umowę zaliczyć możemy do prawa publicznego - również umowa powinna być traktowana jako publicznoprawna ${ }^{76}$. Doktryna niemiecka optuje zatem za jak najczęstszym stosowaniem umowy administracyjnej. Wreszcie $\mathrm{w}$ prawie niemieckim $\mathrm{z}$ umowami administracyjnymi ściśle wiąże się tzw. „zakaz sprzęgania” (Koppelungsverbot ${ }^{77}$ ), a więc zakaz uzależniania wydania aktu administracyjnego przez organ administracji publicznej od świadczenia majątkowego petenta - w sytuacji gdy ustawodawca wyraźnie organu do tego nie upoważnił ${ }^{78}$. Należy przy tym dodać, że w prawie i praktyce niemieckiej umowa administracyjna stosowana jest dość rzadko, regulacja prawna jest fragmentaryczna, stosowanie przepisów VwvfG przysparza zaś istotnych trudności i wciąż jest przedmiotem licznych sporów w doktrynie.

\subsection{Umowa administracyjna w prawie polskim. Sformułowane przez doktrynę wnioski de lege ferenda}

Po przedstawieniu podstawowych zagadnień związanych z umową administracyjną $\mathrm{w}$ prawie niemieckim należy rozważyć, czy oraz $\mathrm{w}$ jakim zakresie umowa ta funkcjonuje w prawie i nauce polskiej. Z jednej strony, skoro umowa administracyjna nie jest instytucją wyodrębnioną w polskim systemie prawnym (np. w k.p.a. czy w przepisach ogólnych prawa administracyjnego), to wnioski na temat umowy administracyjnej

${ }^{74}$ Ibidem. Podobnie Z. Cieślik: „Wystarczającą podstawę stanowiły ogólne zasady prawa, nawet te, jak pacta sunt servanda, czerpane z innych gałęzi niż prawo publiczne" (Z. Cieślik, op. cit., s. 78).

${ }^{75} \mathrm{H}$. Bauer, Die negative und die positive Funktion des Verwaltungsvertragsrechts, w: Der Verwaltungsstaat im Wandel, Festschrift für Franz Knöpfle zum 70. Geburtstag, Hrsg. von D. Merten, R. Schmidt, R. Stettner, München 1996, s. 12 i n., cyt. za: Z. Cieślik, op. cit., s. 78.

${ }^{76}$ J. Wyporska-Frankiewicz, op. cit., s. 234-235; D. Kijowski, Umowy ..., s. 282 i n.

77 Szerzej na ten temat zob. H. Bauer, § 36 Verwaltungsverträge..., w: Grundlagen..., s. $1270,1280,1340$ i n.

${ }^{78}$ J. Wyporska-Frankiewicz, op. cit., s. 234-235; D. Kijowski, W sprawie charakteru prawnego umów..., s. 82-83; A. Kubiak, op. cit., s. 82. 
powinny mieć charakter wniosków de lege ferenda. Z drugiej strony należy zadać pytanie, czy ze względu na obowiązywanie określonych przepisów, w prawie polskim nie funkcjonuje już umowa administracyjna.

Należy podkreślić, że w doktrynie występuje pogląd, w myśl którego $\mathrm{w}$ aktualnie obowiązującym stanie prawnym nie istnieje umowa administracyjna w tzw. "czystej” postaci ${ }^{79}$. W konsekwencji często wskazuje się, że powierzenie przez administrację jej zadań podmiotowi niepublicznemu w drodze czynności dwustronnej następuje w formie umowy cywilnoprawnej ${ }^{80}$. Jednakże większość autorów w polskiej doktrynie prawa publicznego wyraża ostatecznie stanowisko, zgodnie z którym umowa administracyjna w prawie polskim jest możliwa, a nawet wskazana. Jedną ze stron takiej umowy jest podmiot administrujący i podmiot ten, zawierając umowę i zachowując swoistą zwierzchność, dba jednocześnie o ochronę interesu publicznego ${ }^{81}$. Faktem jest jednak, że umowa administracyjna nie została wprowadzona jako prawna forma działania administracji publicznej do k.p.a. ani nie stanowi przedmiotu kontroli sądu administracyjnego na podstawie Prawa o postępowaniu przed sądami administracyjnymi ${ }^{82}$.

Ciekawego spostrzeżenia dokonuje J. Boć, wskazując, że jeśli jakąś wyraźnie określoną część zorganizowanej administracji publicznej wyposażymy w szersze pole lub na podobnym czy takim samym polu w szersze możliwości zawierania umowy administracyjnoprawnej, poszerzymy w ten sposób możliwość decentralizacji o element niepolegający wyłącznie na przekazywaniu kompetencji, ale na wyposażeniu w taką formę działania publicznoprawnego, która niewątpliwie poszerza samodzielność działania ${ }^{83}$.

Ponadto, jak dalej podkreśla J. Boć, idea poszerzenia zastosowania i w rezultacie roli umowy administracyjnej byłaby zgodna z nowym intelektualnym podejściem (ujawnianym w nowych dokumentach i w nowym prawie unijnym), mocniej wskazującym na partycypacyjna rolę jednostek w osiąganiu efektów publicznych ${ }^{84}$. Wreszcie wykorzystanie formy prawnej umowy administracyjnej, jak wskazuje J. Boć, być

\footnotetext{
${ }^{79}$ J. Wyporska-Frankiewicz, op. cit., s. 234-235 i n.

${ }^{80}$ Por. D. Kijowski, Umowy..., s. 284-291; J. Wyporska-Frankiewicz, op. cit., s. 237.

${ }^{81}$ J. Boć, Działalność konsensualna..., s. 266.

${ }^{82}$ Ustawa z dnia 30 VIII 2002 r. - Prawo o postępowaniu przed sądami administracyjnymi (tekst jedn. Dz.U. 2018, poz. 1302 ze zm.), dalej „p.p.s.a.”.

${ }^{83}$ J. Boć, O umowie administracyjnej..., s. 30; idem, Działalność konsensualna..., s. 265; podobnie T. Rabska, op. cit., s. 612.

${ }^{84} \mathrm{~J}$. Boć, O umowie administracyjnej..., s. 30 i n.
} 
może zwiększałoby rolę administracji lokalnej z powodu innego typu wymaganych podstaw prawnych, przez co zwiększałaby ona możliwości własnego działania i efektywność realizacji idei sprawiedliwości, zapomnianej gdzieś w kontekście nieskuteczności coraz liczniejszych środków ochrony i coraz wątlejszych ich rezultatów ${ }^{85}$. Należy podkreślić, że nie są to argumenty nierelewantne; wprowadzenie umowy administracyjnej do polskiego systemu prawnego jest niewątpliwie zgodne z zasadą subsydiarności i zasadą decentralizacji ${ }^{86}$.

De lege ferenda w zakresie umowy administracyjnej J. Boć wskazał, że brak uniwersalności zastosowania umowy administracyjnej (takiej, jaką ma umowa cywilna) nakazuje delimitację obszaru jej zastosowania ${ }^{87}$. Autor konsekwentnie zatem opowiada się przeciwko zasygnalizowanej zasadzie swobody wyboru prawnej formy działania. J. Boć wskazuje, że w celu ograniczenia pola stosowania umowy administracyjnej można się posłużyć: (a) wyróżnieniem charakteru norm prawnych regulujących motywy, warunki, zawieranie, realizację i skutki umowy; (b) wyróżnieniem przedmiotu takiej umowy czy takich umów; (c) wyróżnieniem związanym ze szczególną pozycją jednej czy obydwu stron umowy uwzględniającą zasięg przydanego jej imperium, wynikającą stąd osobowość publicznoprawną, zakres władczości rozciągniętej na formę, treść i trwałość postanowień umownych ${ }^{88}$. Powyższy zabieg umożliwi wyraźne oddzielenie umów administracyjnych od umów cywilnych $^{89}$.

Konkludując swoje propozycje na temat umowy administracyjnej, J. Boć de lege ferenda wskazuje hipotetyczne pola merytoryczne, w których umowa administracyjna mogłaby na gruncie prawa polskiego znaleźć zastosowanie: (1) ustawodawca wyznacza stojące przed organami administracji publicznej zadania, bez jednoczesnego wyznaczania form czynności władczych podejmowanych dla ich realizacji ${ }^{90}$; (2) ustawodawca daje możliwość lub nakazuje osiągnięcie określonego

${ }^{85}$ J. Boć, Działalność konsensualna..., s. 265.

${ }^{86}$ Artykuł 15 ust. 1 Konstytucji Rzeczypospolitej Polskiej z dnia 2 IV 1997 r. (Dz.U. Nr 78, poz. 483 ze zm.) stanowi: Ustrój terytorialny Rzeczypospolitej Polskiej zapewnia decentralizację władzy publicznej.

${ }^{87}$ J. Boć, Działalność konsensualna..., s. 269.

${ }^{88}$ Ibidem.

${ }^{89}$ Ibidem.

${ }^{90}$ Według autora możliwość uznaniowego zastępowania aktu administracyjnego umową administracyjną zagroziłaby w wielu miejscach poprawnemu funkcjonowaniu państwa prawa, a nierzadko poszerzałaby obszar patologii publicznej (ibidem, s. 271). 
rezultatu materialnego, a przewidziane w tym celu formy zindywidualizowanych wypowiedzi władczych przewidują osiągnięcie tego rezultatu ewentualnie, $\mathrm{tj}$. $\mathrm{w}$ razie nieosiągnięcia sytuacji wymaganych wprost przepisami prawa; (3) istnieje możliwość pominięcia dodatkowych procedur przez umowne uzyskanie wyniku równego wynikowi łącznemu procedur ominiętych (co do realizacji określonych zasad i wymogów); (4) istnieje możliwość korzystnego dla obu stron przyśpieszenia jeszcze nieuzyskanego wyniku określonego dotychczasową wypowiedzią władczą; (5) istnieje możliwość skasowania niekorzystnie dla obu stron kontynuujących się skutków faktycznych dotychczasowych działań władczych ${ }^{91}$.

Obszernie na temat umowy administracyjnej wypowiadał się A. Panasiuk $^{92}$. Według tego autora umowa administracyjna powinna charakteryzować się: „1) tym, że zawsze jedną lub obu ${ }^{93}$ stronami takiej umowy jest podmiot publiczny; 2) umiejscowieniem przedmiotu umowy w sferze realizacji zadań publicznych; 3) tym, że realizowane zadania publiczne urzeczywistniają interes publiczny; 4) względną swobodą zawierania umowy, ograniczoną jedynie konkurencyjno-eliminacyjnymi procedurami wyboru partnera; 5) jednoznacznym określeniem rozdziału zadań i czynności podmiotu prywatnego oraz obowiązków podmiotu publicznego, ewentualnie rozdzieleniem takich zadań i czynności między podmiotami publicznymi, będącymi stronami umowy; 6) jasnym określeniem odpowiedzialności za dokonywane czynności oraz efekt końcowy; 7) określeniem zasad sprawowania nadzoru i kontroli nad sposobem realizacji powierzonych zadań publicznych"94.

J. Wyporska-Frankiewicz również, podobnie jak A. Panasiuk, podjęła próbę wyodrębnienia cech istotnych umowy administracyjnej. Według tej autorki, po pierwsze, zawsze co najmniej jedną stroną takiej umowy będzie podmiot administracji, a umowa zawierana jest w zakresie jego kompetencji ${ }^{95}$. Nadto zazwyczaj będzie on tą "silniejszą" stroną umowy, co przejawia się w tym, że to on ostatecznie decyduje, czy do zawarcia konkretnej umowy dojdzie ${ }^{96}$. Po drugie, przedmiot takiej umowy

\footnotetext{
${ }^{91}$ Ibidem.

${ }^{92}$ A. Panasiuk, op. cit., s. 30.

${ }^{93}$ A. Panasiuk nieprawidłowo zakłada tożsamość pojęć „umowa administracyjna” oraz "umowa publicznoprawna”, wskazując, że w literaturze prawniczej przyjęto uważać te pojęcia za tożsame (ibidem, s. 18).

${ }^{94}$ Ibidem, s. 30.

${ }^{95}$ J. Wyporska-Frankiewicz, op. cit., s. 236.

${ }^{96}$ Ibidem.
} 
musi pozostawać w związku z wypełnianiem służby publicznej97, a tym samym służy realizacji celu publicznego ${ }^{98}$. Umowa administracyjna reguluje stosunki prawa administracyjnego i dotyczy wykonywania zadań z zakresu administracji publicznej, ale może też kształtować indywidualną sprawę lub nieokreśloną liczbę spraw ${ }^{99}$. Spory wynikłe na jej tle poddane zostały kognicji sądów administracyjnych ${ }^{100}$.

Warto wskazać, że także B. Popowska stoi na stanowisku, iż umowa administracyjna powinna podlegać kontroli sądu administracyjnego ${ }^{101}$. Należy podkreślić, że jedynie część autorów zwraca uwagę na powyższy aspekt dotyczący umowy administracyjnej. Przy czym, co ważne, podleganie kontroli sądu administracyjnego świadczy w dużym stopniu o publicznoprawnym charakterze prawnej formy działania. Wydaje się, że w obecnym stanie prawnym do stwierdzenia, że umowa ma cechy administracyjnej, nie jest konieczne podleganie jej kontroli sądu administracyjnego. Przynajmniej tak sprawy nie stawia większość przywoływanych autorów, w szczególności J. Boć oraz A. Panasiuk. Uznanie, że przedmiotowe kryterium jest istotne, doprowadziłoby do sytuacji, w której wszystkie umowy normowane w całości lub części prawem publicznym nie mogłyby być uznane za administracyjne, ponieważ - jak wynika z p.p.s.a. - umowa nie podlega kontroli sądu administracyjnego. Wyciągając wnioski z powyższych rozważań, należy de lege ferenda stanąć na stanowisku, że można mówić o umowie administracyjnej w aspekcie materialnoprawnym. Natomiast brak kontroli sądu administracyjnego nad zawieraniem umowy administracyjnej wyklucza taki wniosek w sensie proceduralnym.

J. Lemańska także wyróżnia cechy właściwe umowy administracyjnej ${ }^{102}$. Przykładowo, według autorki przedmiot umowy administracyjnej związany jest $\mathrm{z}$ zadaniami administracji ${ }^{103}$. W konkluzji swoich rozważań podkreśla, iż mimo że ustawodawca polski nie wprowadził dotychczas do obrotu prawnego wprost takiej formy działania, jaką jest umowa administracyjna, to do jej wykształcenia dochodzi w wyniku pewnej praktyki ${ }^{104}$.

${ }^{97}$ Pojęcie służby publicznej nawiązuje do doktryny francuskiej - por. A. Śledzińska, op. cit., s. 181.

${ }^{98}$ J. Wyporska-Frankiewicz, op. cit., s. 236.

${ }^{99}$ Ibidem.

100 Por. ibidem.

101 B. Popowska, Decyzja i umowa..., s. 114.

102 J. Lemańska, Umowa administracyjna a umowa cywilna, w: Instytucje..., s. 421-427.

${ }^{103}$ Ibidem.

104 Ibidem, s. 427. 
Wśród przepisów prawa można odnaleźć takie formy prawne działania administracji publicznej, których w żadnym razie nie można zakwalifikować jako umowy cywilnoprawnej ze względu na to, że (1) normowane są wyłącznie przepisami prawa publicznego, a (2) ich zawarcie wyłącza możliwość wydania w sprawie decyzji administracyjnej bądź kształtuje jej treść, albo też zawarcie umowy warunkuje wydanie decyzji ${ }^{105}$.

Na podstawie wyżej przytoczonych poglądów doktryny można przedstawić najistotniejsze cechy, którymi powinna się charakteryzować konstrukcja teoretyczna umowy administracyjnej. Po pierwsze, powinien ją zawierać podmiot administracji publicznej na podstawie posiadanej kompetencji. Skoro w polskim prawie funkcjonuje porozumienie administracyjne dotyczące podmiotów z administracji, umowa administracyjna powinna dotyczyć relacji administracji z obywatelami. Po drugie, przedmiot umowy powinien być uregulowany prawem publicznym i dotyczyć wyłącznie realizacji zadań z zakresu administracji publicznej. I po trzecie, nie można pominąć kwestii, że spory powstałe na tle umowy administracyjnej powinny zostać poddane kognicji sądów administracyjnych. Z punktu widzenia ochrony prawnej jednostki jest to, oczywiście, sprawa bardzo istotna.

Zdaniem D. Kijowskiego umowa administracyjna powinna zostać generalnie uregulowana w k.p.a. ${ }^{106}$ Przepisy te powinny co najmniej definiować pojęcie umowy administracyjnej, ustalać ogólne granice dopuszczalności jej zawierania oraz pomocniczego stosowania przepisów prawa cywilnego ${ }^{107}$. Podobnie J. Wyporska-Frankiewicz stwierdza, że ze względu na fakt, iż umowa administracyjna miałaby zastępować decyzję administracyjną, należałoby rozważyć, czy przypadkiem nie uzupełnić przepisów k.p.a. o stosowną regulację ${ }^{108}$. Powyższe postulaty wydają się jak najbardziej uzasadnione, choć istnieją inne sposoby uregulowania umowy administracyjnej w prawie, np. w postaci przepisów ogólnych prawa administracyjnego.

Polski ustawodawca rozważał wprowadzenie umowy administracyjnej do polskiego systemu prawnego ${ }^{109}$. Umowa administracyjna w projekcie była uregulowana dość szeroko. Niestety, ze względu na

105 Ibidem.

${ }^{106}$ D. Kijowski, W sprawie charakteru prawnego umów..., s. 87.

107 Ibidem.

108 J. Wyporska-Frankiewicz, op. cit., s. 236 i n.

109 Por. projekt z dnia 29 XII 2010 r. ustawy - Przepisy ogólne prawa administracyjnego (druk sejmowy nr 3942/VII kadencja). 
dyskontynuację prac parlamentu Przepisy ogólne prawa administracyjnego nie stały się elementem polskiego systemu prawnego ${ }^{110}$. Ponadto w toku nowelizacji k.p.a. (w latach 2016-2017) pojawiła się propozycja włączenia umowy administracyjnej do tego aktu. Jednakże kwestia umowy administracyjnej została wyłączona z projektu jeszcze przed etapem rozpoczęcia prac parlamentarnych ${ }^{111}$. Należy stanąć na stanowisku, że prace nad wprowadzeniem do polskiego systemu prawnego umowy administracyjnej powinny zostać wznowione.

Definicję umowy administracyjnej określał art. 41 ust. 1 Przepisów ogólnych prawa administracyjnego, zgodnie z którym "organ administracji publicznej, właściwy do załatwienia sprawy administracyjnej w drodze decyzji administracyjnej albo poprzez podjęcie innego aktu lub czynności władczej, uprawniony jest do zawarcia umowy z osobami, których interesów prawnych lub obowiązków sprawa dotyczy, o ile nie stoją temu na przeszkodzie przepisy szczególne (umowa administracyjna)".

Zaprezentowana definicja umowy administracyjnej uwzględnia, przynajmniej w pewnym zakresie, postulaty doktryny ${ }^{112}$. Jednakże dopóki przedmiotowa regulacja nie stanie się obowiązującym prawem, dyskusja nad formułą umowy administracyjnej pozostaje otwarta.

\subsection{Umowa administracyjna w prawie polskim - rozważania de lege lata}

Polska doktryna prawa administracyjnego oraz publicznego prawa gospodarczego rozważała, czy za umowę administracyjną można uznać umowę o partnerstwie publiczno-prywatnym ${ }^{113}$. Szczególnie na

${ }^{110} \mathrm{~W}$ związku z powyższym, niestety, mimo postulatów wielu przedstawicieli doktryny, umowa administracyjna nie stała się częścią polskiego systemu prawnego - por. np. B. Popowska, Partnerstwo publiczno-prywatne w świetle koncepcji "ciagu działań prawnych" i jej wptyw na ocene umowy o ppp, w: Środki prawne publicznego prawa gospodarczego, pod red. L. Kieresa, Wrocław 2007, s. 168-174.

${ }^{111}$ Zob. Rządowy projekt ustawy o zmianie ustawy - Kodeks postępowania administracyjnego oraz niektórych innych ustaw (druk sejmowy nr 1183/VIII kadencja).

112 Proponowana regulacja spotkała się z krytyką J. Bocia, który podniósł, że stanowi ona "prostą drogę do ucywilnienia wszystkich stosunków administracyjnoprawnych" (J. Boć, Działalność konsensualna..., s. 268).

${ }^{113}$ Artykuł 1 Ustawy z dnia 19 XII 2008 r. o partnerstwie publiczno-prywatnym (tekst jedn. Dz.U. 2015, poz. 696, dalej „ustawa o ppp”) stanowi: „1. Ustawa określa zasady współpracy podmiotu publicznego i partnera prywatnego w ramach partnerstwa publiczno-prywatnego oraz organ właściwy w sprawach partnerstwa publiczno-prywatnego 
klasyfikację prawną umowy o partnerstwie jako umowy administracyjnej wskazują strony tej umowy, jakimi są podmiot publiczny i partner prywatny. Jednakże wątpliwości wzbudziła treść stosunku prawnego między stronami takiej umowy. Zdaniem przedstawicieli doktryny umowa o partnerstwie publiczno-prywatnym ma charakter cywilnoprawny, ponieważ regulacje ustawy o ppp dotycza, co do zasady, stosunków cywilnoprawnych. Jak bowiem słusznie podkreśla B. Popowska, ustawa o ppp nie obejmuje całokształtu stosunków (w tym publicznoprawnych) występujących między pomiotem publicznym i podmiotem prywatnym w związku z partnerstwem publiczno-prywatnym, ograniczając się do stosunków o charakterze prywatnoprawnym, przybierających formę cywilnoprawnej umowy o ppp o określonej treści ${ }^{114}$. Z kolei według J. Zimmermanna jest to odmiana umowy cywilnoprawnej, która nie może zastąpić aktu administracyjnego ${ }^{115}$. Nie można przeoczyć faktu, że partnerstwo publiczno-prywatne nie jest poddawane kontroli sądu administracyjnego ${ }^{116}$. Inni przedstawiciele doktryny również przychylają się do stanowiska, że umowa o partnerstwie publiczno-prywatnym stanowi, w zasadzie, umowę cywilnoprawną ${ }^{117}$. Należy zgodzić się z tym poglądem - w obecnym stanie prawnym, zważywszy na fakt, że ustawa o ppp reguluje cywilnoprawne prawa i obowiązki stron, umowa o partnerstwie publicznoprawnym ma charakter cywilnoprawny.

uregulowanych w ustawie. 2. Partnerstwo publiczno-prywatne polega na wspólnej realizacji przedsięwzięcia opartej na podziale zadań i ryzyk pomiędzy podmiotem publicznym i partnerem prywatnym". Na temat pojęcia partnerstwa publiczno-prywatnego por. M. Kania, Partnerstwo publiczno-prywatne, w: Publiczne prawo gospodarcze, s. 562-592.

${ }_{114}$ B. Popowska, Partnerstwo publiczno-prywatne..., s. 171, 173. Nie można przeoczyć faktu, że autorka formułuje powyższe uwagi w odniesieniu do umowy o ppp na gruncie ustawy o ppp z 2005 r. (Ustawa z dnia 28 VII 2005 r. o partnerstwie publiczno-prywatnym, Dz.U. 2005 Nr 169, poz. 1420). Należy jednak podkreślić, że powyższe uwagi są aktualne także w odniesieniu do obecnego stanu prawnego ustawy o ppp, ponieważ charakter prawny umowy o partnerstwie publiczno-prywatnym nie uległ zmianie.

115 J. Zimmermann, Prawo administracyjne, s. 349.

116 Ibidem.

117 Por. A. Piszcz, op. cit., s. 259-261 i n.; M. Rudnicki, Partnerstwo publiczno-prywatne. Wybrane zagadnienia prawnoustrojowe i prawnofinansowe, "Samorząd Terytorialny" 2006, nr 7-8, s. 70-71 i n.; A. Miruć, Partnerstwo publiczno-prywatne jako sposób realizacji zadań publicznych, w: Koncepcja systemu prawa administracyjnego..., s. 482 i n.; A. Tyśkiewicz-Mazur, Umowa o partnerstwie publiczno-prywatnym - wybrane zagadnienia, "Samorząd Terytorialny" 2008, nr 11, s. 20 i n.; K. Płonka-Bielenin, Charakter prawny umowy o partnerstwo publiczno-prywatne, "Samorząd Terytorialny" 2009, nr 9, s. 12 i n.; W. Gonet, Partnerstwo publiczno-prywatne jako forma realizacji zadań w jednostkach samorzadu terytorialnego, „Finanse Komunalne" 2007, nr 7, s. 46 i n. 
Przesądzające dla powyższego stwierdzenia są: brak regulacji w zakresie realizacji zadań publicznych przez strony takiej umowy, a także brak kontroli sądów administracyjnych w odniesieniu do omawianej umowy.

\section{Podsumowanie}

W ramach wypracowanej przez doktrynę prawa administracyjnego konstrukcji prawnych form działania administracji publicznej można wyróżnić zarówno umowę cywilnoprawną (prywatnoprawną), jak i umowę odpowiadającą charakterystyce umowy administracyjnej. Przeprowadzona analiza pozwoliła wyodrębnić podstawowe cechy, którymi powinna się charakteryzować konstrukcja teoretyczna umowy administracyjnej: (1) powinien ją zawierać podmiot administracji publicznej na podstawie posiadanej kompetencji, (2) w ramach realizacji zadań publicznych, (3) spory powstałe na tle umowy administracyjnej powinny zaś zostać poddane kognicji sądów administracyjnych.

Jakkolwiek ustawodawca nie zdecydował się na wprowadzenie do polskiego systemu prawnego umowy administracyjnej, to wiele z już funkcjonujących na gruncie polskiego prawa umów ma pewne cechy, które przynajmniej w części przypominają umowę administracyjną opisaną powyżej. Taka umowa administracyjna de lege lata dotyczy relacji: administracja publiczna - obywatel i jest zawierana w związku z realizacją zadań publicznych. De lege ferenda zawieranie umowy administracyjnej powinno podlegać kontroli sądów administracyjnych, ponieważ zapewniłoby to obywatelowi odpowiedni poziom ochrony prawnej. Tym samym umowa administracyjna byłaby właściwą formą prawną działania administracji publicznej, gdyż polepszałaby sytuację prawną obywatela.

\section{AGREEMENT AS A LEGAL FORM OF OPERATION OF PUBLIC ADMINISTRATION IN POLISH AND GERMAN DOCTRINE OF PUBLIC LAW}

\section{S u m mary}

Within the administrative construction of legal forms of public administration activity developed by the doctrine of administrative law, one may distinguish both a civil-law contract (private-law), as well as an agreement having certain features of a public-law contract. 
The German doctrine of public law, has long been struggling with problems of legal qualification of contracts used as legal forms of action by public administration entities. As part of the work undertaken by the German doctrine of public law, a two step theory, a concept of contract law in administration and a model administrative contract have been developed.

Approximation of these theories allowed the Polish doctrine of public law to identify the most important features, which should characterise the theoretical construction of a public-law contract concluded with a citizen or an administrative contract. First of all, it should be concluded by a public administration entity on the basis of its competence. The administrative agreement should concern the relationship between the administration and the citizens. Secondly, the subject matter of the contract should be governed by public law and relate exclusively to the performance of public administration tasks. Thirdly, disputes arising from an administrative agreement should be submitted to the jurisdiction of administrative courts. The article shows that from the point of view of legal protection of the individual this is a crucial matter.

Although the legislator has not decided to introduce an administrative agreement into the Polish legal system, many of the contracts already in operation under Polish law have certain features which at least in part resemble the administrative agreement described above. Such an administrative agreement often concerns the relationship between public administration and the citizen and is concluded in connection with the performance of public tasks. De lege ferenda the conclusion of an administrative contract should be subject to review by the administrative courts.

Keywords: legal forms of operation - administrative agreement - contract law in administration - general provisions of administrative law 